\title{
PERENCANAAN PEMBELAJARAN CREATIVE LEARNING DALAM MATA KULIAH PROFESI KEGURUAN
}

\author{
Beti Istanti Suwandayani $^{1}$, Siti Fatimah Soenaryo ${ }^{2}$, \& Reny Dwi Susanti ${ }^{3}$
}
1. Fakultas Keguruan dan Ilmu Pendidikan, Universitas Muhammadiyah Malang beti.istanti@gmail.com ( 085649843677$)$

2. Fakultas Keguruan dan Ilmu Pendidikan, Universitas Muhammadiyah Malang fatimahsoenaryo@yahoo.co.id

3. Fakultas Keguruan dan Ilmu Pendidikan, Universitas Muhammadiyah Malang renydwy21@gmail.com

\begin{abstract}
ABSTRAK
Kehidupan di era milenial ini menuntut berbagai ketrampilan yang harus dikuasai manusia, sehingga diharapkan pendidikan dapat memberikan persiapan bagi peserta didik untuk menguasai berbagai ketrampilan tersebut. Pencapaian ketrampilan pada abad ke-21 tersebut dapat dilakukan melalui perbaharuan dalam kualitas pembelajaran. Penelitian ini bertujuan untuk menganalisis implementasi perencanaan, kendala dalam perencanaan pembelajaran, dan solusi dalam perencanaan pembelajaran creative learning. Metode yang digunakan dalam penelitian ini adalah penelitian deskriptif kualitatif. Pengumpulan data yang digunakan adalah observasi, wawancara dan dokumentasi. Teknik pengumpulan data ini menggunakan instrumen sebagai pedoman pengumpulan data. Analisis data dalam penelitian ini menggunakan analisis deskriptif berupa paparan yang mendalam terkait data penelitian ini. Hasil penelitian ini menunjukkan perencanaan pembelajaran dilakukan sebelum pembelajaran dengan mempersiapkan perangkat pembelajaran berupa RPS mata kuliah. Permasalahan yang muncul dalam perencanaan pembelajaran ini adalah memadukan perencanaan pembelajaran dengan perkembangan milenial. Sedangkan untuk mengatasi permasalahan tersebut pada pembelajaran creative learning adalah dengan melakukan inovasi pendampingan pembuatan media dan pembelajaran berbasis teknologi.
\end{abstract}

Kata Kunci: Perencanaan Pembelajaran, Creative Learning, Keguruan

\section{PENDAHULUAN}

Pendidikan merupakan kebutuhan yang wajib diterima setiap individu tanpa perlu memandang dari segi ekonomi, budaya atau sosial individu tersebut berasal. 
Melalui pendidikan suatu bangsa dapat menciptakan bangsa yang tangguh, mandiri, berkarakter dan berdaya saing. Oleh karena itu, pendidikan menjadi salah satu wadah bagi manusia untuk belajar, mengembangkan potensi dan pendidikan yang sebagai sarana untuk memberikan suatu pengarahan serta bimbingan yang diberikan kepada peserta didik dalam pertumbuhannya untuk membentuk siswa menuju kedewasaan.

Pendidikan merupakan proses untuk membantu manusia dalam mengembangkan dirinya dan meningkatkan harkat dan martabat manusia, sehingga manusia mampu menghadapi setiap perubahan yang terjadi menuju arah yang lebih baik. Melalui pendidik, masyarakat Indonesia dapat meningkatkan pengetahuan, kemampuan dan kretaivitas terhadap perkembangan ilmu pengetahuan dan teknologi. Fungsi lain dari pendidikan adalah mengurangi penderitaan rakyat dari kebodohan, keterbelakangan dan kemiskinan, karena ilmu pengetahuan dan ketrampilan yang diperoleh dapat membawa seseorang untuk mampu mengatasi problematika kehidupan.

Pendidikan mempunyai peranan yang sangat menentukan bagi perkembangan dan perwujudan diri individu, terutama bagi pembangunan bangsa dan negara. Proses pendidikan yang bermutu akan membuahkan hasil pendidikan yang bermutu dan relevan dengan pembangunan. Tantangan bagi pendidikan untuk memberikan pemecahan masalah pembelajaran dan secara tidak langsung proses pembelajaran akan menjadi lebih baik, sehingga bermutu dan relevan dapat tercapai. Dalam membelajarkan peserta didik dapat melalui pengajaran atau pembelajaran yang bermutu. Pembelajaran merupakan bagian dalam proses peningkatan kualitas pendidikan karena dengan kualitas pendidikan yang optimal, diharapkan akan dicapai keunggulan sumber daya manusia yang siap untuk menghadapi persaingan pada era globalisasi. Pembelajaran merupakan aktivitas yang paling utama dalam pendidikan, karena dalam pembelajaran terdapat porses yang dilakukan individu untuk memperoleh sutau perubahan perilaku yang baru secara keseluruhan.

Proses pembelajaran pada dasarnya untuk mengembangkan aktivitas dan kreativitas peserta didik melalui berbagai interaksi dan pengalaman belajar. Sehingga dengan minat belajar peserta didik untuk belajar meningkat dan kualitas pembelajaran dapat tercapai. Peningkatan kualitas pembelajaran menuntut kemandirian pendidik untuk menciptakan dan mengelola kelas yang kondusif. Hal ini bertujuan untuk mengembangkan aktivitas dan kreativitas belajar peserta didik secara optimal sesuai dengan kemampuannya. Undang -Undang sistem pendidikan nasional 2 tahun 1989 tentang sistem pendidikan nasional adalah sebagai berikut: Pendidikan nasional bertujuan mencerdaskan kehidupan dan mengembangkan manusia yang beriman dan bertaqwa terhadap Tuhan Yang Maha Esa dan berbusi luhur, memiliki pengetahuan dna ketrampilan, eksehatan jasmani dan rohani, kepribadian yang mantap dan mandiri 
serta memiliki rasa tanggung jawab kemasyarakatan dan kebangsaan (UndangUndang Republik Indonedia, 1989: 6).

Pendidikan yang berkualitas sangat penting untuk menyiapkan peserta didik dalam persaingan era globalisasi. Dunia pendidikan untuk mempersiapkan peserta didik agar mampu menguasai dan mengembangkan ilmu pengetahuan dan teknologi, kreativitas dan kecerdasan serta berkepribadian unggul. Untuk mempersiapkan pendidikan yang berkualitas tersebut diperlukan persiapan yang matang dalam pembelajaran. Dalam konteks pengajaran, ada beberapa tahapan yang harus dilakukan, yaitu perencanaan, pelaksanaan dan evaluasi. Perencanaan dapat diartikan sebagai serangkaian proses untuk menyusun model, pendekatan, strategi, metode dan bahan ajar serta penilaian dalam lama waktu tertentu untuk mencapai target yang diharapkan. Pendidik yang mengabaikan kegiatan perencanaan pembelajaran maka dalam pelaksanaan pembelajaran akan menjadi kurang terarah, sehingga proses pembelajaran kurang optimal.

Pendidik dituntut untuk menciptakan suasana belajar yang efektif, inovatif dan menyengakan (Nadzir, 2013). Berdasarkan hal tersebut perencanaan pemeblajaran menjadi amat penting untuk dilakukan pendidik agar komponen pembelajaran dapat terorganisir dengan baik. Perencanaan adalah proses petepatan dan pemanfaatan sumber daya secara terpadu untuk menunjang kegaitan pelaksanaan pembelajaran secara efisien dan efektif dalam mencapai tujuan pembelajaran. Perencanaan merupakan proyeksi tentang apa yang diperlukan dalam rangka mencapai tujuan yang bernilai dan absah (Roger A. Kaufman: Harjanto, 1997: 2). Perencanaan sebagai jembatan untuk menghubungkan tujuan pembelajaran dengan pelaksanaan kegiatan pembelajaran. Tentunya perencanaan mendahului pelaksanaan suatu kegiatan, karena dengan perencanaan akan menentukan bagaimana harus pergi dan cara yang efektif dan efisien. Berdasarkan hal tersebut perencanaan mengandung pengertian yaitu mencakup kegiatan merupmuskan tujuan apa yang akan dicapai oleh suatu kegiatan pembelajaran, cara apa yang akan disamapaikan dan bagaimana caranya serta alat atau media yang diperlukan (Ibrahim, 1993). Sedangkan menurut Sudjana (1988) perencanaan pembaljaran merupakan kegiatan memproyeksikan tindakan dalam apa yang akan dilaksanakan dalam proses kegiatan belajar mengajar. Dalam praktik perencanaan pembelajaran yang harus diperhatikan sehingga proses belajar mengajar di kelas dapat dilaksanakan secara efektif adalah sebagai berikut (Sagala, 2003).

1) Membatasi sasaran atas dasar tujuan intrusional khusu dan menetapkan pelaksanaan kerja untu mencapai hasil yang maksimal sesuai dengna tujuan pembelajaran. 
2) Menetapkan apa, kapan dan bagaimana cara yang akan dilakukan oleh guru dalam pelaksanaan pembelajaran.

3) Mengembangkan berbagai alternatif yang sesuai dengan tujuan pemeblajaran.

4) Mengumpulkan dan menganalisis data yang penting untuk mendukung kegiatan pembelajaran.

5) Mempersipakan dan mengomunikasikan rencana dan keputusan yang berkaiyan dengan pembelajaran kepada pihak yang berkepentingan.

Sehingga apabila beberapa prinsip tersebut dilaksanakan maka secara teoritik pembelajaran akan dapat mencapai tujuan sesuai dengan rencana yang telah disusun. Hal tersebut sejalan dengan pendapat Mulyasa (2003) yaitu. 1) Kompetensi yang disusun jelas, mudah diamati. 2) perencanaan pembelajaran harus sederhana dan fleksibel, serta dapat dilaksanakan dala kegiatan pembelajaran dan pembentukan peserta didik. 3) Kegiatan-kegiatan yang disusun dan dikembangkan dalma perencanaan pembelajaran harus menunjang dan sesuai dengan komptensi yang telah ditetapkan, dan 4) Perencanaan pembelajaran yang dikembangkan harus utuh dan menyeluruh serta jelas pencapaiannya.

Karakteristik belajar yang dituntut saat ini adalah model pembelajaran yang dapat memberlajarkan peserta didik secara aktif dan kreatif yang sesuai dengan potensi dan perkermbangan peserta didik. Hal ini menuntut seorang pendidik untuk dapat memdesain, melaksanakan dan mengevaluasi pembelajaran yang optimal. Pendidik harus mampu mulai dari 1) mendesain pembelajaran yang berkarakteristik pada pengembangan belajar peserta didik aktif, 2) memotivasi siswa dalam belajar, 3) mengelola kelas sehingga menghasilkan aktivitas yang total, 4) memberikan latihan, praktik atau tugas esesisal maupun di rumah yang tepat sehingga mendorong peserta didik aktif, 5) memilih dan menggunakan strategi belajar yang memiliki karakteristik aktivitas peserta didik yang tinggi, 6) mampu melakukan penilaian yang menyeluruh, 7) mampu memilih dan menerapkan pemberdayaan media dan sumber belajar dalam mendukung aktivitas peserta didik.

Berdasarkan hasil obervasi dan wawancara yang dilakukan dengan dosen mata kuliah Profesi Keguruan di Program Studi Pendidikan Guru Sekolah Dasar, Fakultas Keguruan dan Ilmu Pendidikan Universitas Muhammadiyah Malang didapatkan informasi bahwa dalam pembelajaran dosen berusaha untuk memberdayakan kemampuran berpikir kreatif peserta didik sehingga peserta didik memiliki ketrampilan berpikir keratif yang masih rendah dan belum terbimbing. Pembelajaran kreatif merupakan komponen yang penting untuk kesuksesan seorang dalam menjalani aktivitas hidup,

Fakultas Keguruan dan Ilmu Pendidikan Universitas Muhammadiyah Malang sebagai salah satu perwujudan dalam menyukseskan pembangunan secara nasional 
dalam bidang pendidikan. Melalui mata kuliah profesi keguruan ini akan dideskripsikan perencanaan pembelajaran yang disiapkan sebelum perkuliahan dimulai. Kegiatan pembelajaran akan menjadi lebih optimal jika seorang pendidik telah mempersipakan perencanaan pembelajaran. Selain itu, seorang pendidik diharapkan dapat menjadi lebih inovatif dalam merepresentasikan perencanaan pembelajaran yang telah dibuat ke dalam kegiatan belajar yang sebenarnya. Sehingga tujuan dilaksanakan penelitian ini adalah untuk memberikan gambaran deskripif perencanaan pelaksanaan creative learning, permasahan dalam menyusun perencanaan pelaksanaan creative learning dan solusi dalam permasalahan perencanaan pelaksanaan creative learning. Hasil yang diharapkan dalam penelitian penerapan model pembelajaran creative learning pada mata kuliah profesi keguruan adalah terdapat temuan terkait implementasi, faktor pendukung, faktor penghambat serta upaya yang dilakukan dalam mengantisipasi faktor penghambat dalam penerapan model pembelajaran creative learning pada mata kuliah profesi keguruan. Target yang diinginkan adalah terimplementasikannya model pembelajaran creative learning dan pengarsipan perangkat pembelajaran pada mata kuliah profesi keguruan sehingga temuan dan luaran dapat tercapai dengan jelas.

\section{METODE PENELITIAN}

Pada bagian metode penilitian ini dipaparkan desain metode penelitian yang digunakan melalui sumber data, prosedur pelaksanaan, intrumen penelitian dan analisis data. Jenis penelitian pada penelitian ini adalah penelitian deskriptif kualitatif. Penelitian deskriptif ini berusaha untuk menggambarkan suatu gejala sosial dengan mendeskripsikan sifat tertentu yang sedang berlangsung. Jenis penelitian ini memberikan informasi secara detail sehingga bermanfaat bagi perkembangan ilmu pengetahuan serta lebih banyak dapat diterapkan pada berbagai permasalahan.

Waktu penelitian ini adalah pada bulan September 2018 pada mahasiswa semester 1 dalam mata kuliah Profesi Keguruan di Program Studi S1 Pendidikan Guru Sekolah Dasar, Fakultas Keguruan dan Ilmu Pendidikan, Universitas Muhammadiyah Malang. Jenis pengumpulan data yang digunakan adalah pengamatan (observasi), wawancara dan dokumentasi. Observasi dilakukan di dalam kelas pada mata kuliah Profesi Keguruan untuk mengetahu bagaimana proses perencanaan yang disiapkan oleh dosen pengampu, mengamati kendala yang dihadapi dalam penyusunan perencanaan, serta solusi yang dihadapi dalam penyusunan perencanaan. Berikut adalah kisi-kisi yang digunakan dalam melaksanakan observasi dalam penelitian ini.

Tabel 1. Intrumen Observasi

\begin{tabular}{cl}
\hline No & \multicolumn{1}{c}{ Aspek } \\
\hline 1. & $\begin{array}{l}\text { Pemilihan kompetensi dasar dengan } \\
\text { topik }\end{array}$ \\
\hline
\end{tabular}




\begin{tabular}{clr}
\hline 2. & $\begin{array}{l}\text { Perumusan indikator } \\
\text { komptensi dengan kompetensi dasar }\end{array}$ \\
\hline 3. & $\begin{array}{l}\text { Perumusan tujuan } \\
\text { dengan indikator } \\
\text { kompetensi }\end{array}$ & $\begin{array}{r}\text { pembelajaran } \\
\text { pencapaian }\end{array}$ \\
\hline 4. & $\begin{array}{l}\text { Kejelasan dalam menyusun materi } \\
\text { pembelajaran }\end{array}$ \\
\hline 5. & $\begin{array}{l}\text { Kejelasan } \\
\text { pembelajaran dengan kompetensi } \\
\text { dasar }\end{array}$ \\
\hline 6. & $\begin{array}{l}\text { Kesesuaian dengan metode, materi } \\
\text { dan karakteristik peserta didik }\end{array}$ \\
\hline 7. & $\begin{array}{l}\text { Kejelasan perancangan } \\
\text { pembelajaran/ langkah kegiatan }\end{array}$ \\
\hline 8. & $\begin{array}{l}\text { Kerincian dan kejelasan skenerio } \\
\text { pembelajaran }\end{array}$ \\
\hline 9. & $\begin{array}{l}\text { Ketepatan dalam kegiatan penutup } \\
\text { pemelajaran }\end{array}$ \\
\hline 10. & $\begin{array}{l}\text { Penilaian mencakup beberapa sikap, } \\
\text { pengetahuan dan ketrampilan }\end{array}$ \\
\hline
\end{tabular}

Sedangkan wawancara yang digunakan adalah jenis wawancara mendalam. Kisikisi yang digunakan dalam penelitian ini adalah 1) persiapan rencana pelaksanaan pembelajaran, 2) upaya dosen pengampu dalam mengondusifkan pembelajaran, 3) menyediakan media dalam proses pembelajaran, 4) mempertimbangkan validasai dan relevansi materi, 5) menyusun materi pembelajaran yang akan digunakan dalam pembelajaran, dan 6) sumber pembelajaran yang digunakan. Dalam teknik dokumentasi penelitian ini adalah sebagai sumber pendukung. Dokumentasi yang digunakan dalam penelitian ini adalah dokumen perencanaan pembelajaran dan foto kegiatan pembelajaran.

\section{HASIL DAN PEMBAHASAN}

Peneliti memperoleh data mengenai perencanaan creative learning yang dilakukan pada mata kuliah Profesi Keguruan di Program Studi S1 Pendidikan Guru Sekolah Dasar, Fakultas Keguruan dan Ilmu Pendidikan, Universitas Muhammadiyah Malang. Deskripsi hasil penelitian adalah sebagai berikut.

\section{A. Implementasi Perencanaan Creative Learning}

Berdasarkan hasil dan temuan dengan metode observasi, wawancara dan dokumentasi pada mata kuliah Profesi Keguruan. Kreativitas merupakan hal yang sangat penting dalam pembelajaran dan pendidik dituntut untuk mendemontrasikan dan menunjukkan proses kreativitas tersebut. Adapun ciri-ciri peserta didik yang kreatif adalah memiliki rasa ingin tahu, mengajukan pertanyaan yang berbobit, memberikan banyak gagasan terhadap suatu masalah dan mempunyai daya imajinasi yang kuat. Dalam melakukan pembelajaran mata kuliah Profesi Keguruan, pendidik melakukan persiapan pembelajaran tersebt agar dalam proses pembelajaran dapat tercapai dengan maksimal. 
Sebagai persiapan mengajar dosen pada mata kuliah Profesi Keguruan dengan menyusun RPS (Rencana Pembelajaran Semester). RPS ini adalah dokumenyaso perencanaan pembelajaran yang disusun sebagai panduan bagi mahasiswa dalam melaksanakan kegiatan perkuliahan selama satu semester untuk mencapai capaian pembelajaran yang telah ditetapkan. Sebelum menyusun RPS, kurikulum yang digunakan di program studi ini adalah Kurikulum Perguruan Tinggi.

Berdasarkan hasil wawancara yang dilakukan oleh peneliti terhadap dosen menunjukkan bahwa perencanaan disusun sebelum perkuliahan dimulai. Penyusununan RPS dilakukan oleh tim dosen di PGSD melalui koordinasi bersama untuk membuat kesepahaman presepsi dalam pengusunan RPS. Setelah itu baru dilakukan penyusunan oleh tim pengembang RPS. Pemyusunan RPS sesuai dengan template yang sudah disepakati oleh Fakultas dan dibreakdown ke program studi PGSD. Data data tersebut diperkuat dengan data dokumentasi yang dilakukan oleh penelti. Berdasarkan kelengkapan perencanaan pembelajaran, dosen telah mengusun RPS dengan lengkap. Penyusunan tersebut sudah direncanakan mulai pertemuan pertama hingga terakhir.

Dalam pembelajaran creative learning disusun pada pertemuan awal karena untuk memunculkan ide kreatif dan inovatif. Sehingga pertemuan pertemuan selanjutnya sudah mulai terbiasa untuk menumbukhkan ide kreatif. Berdasarkan dokumentasi RPS sudah disusun cukup baik. Hal ini dibuktikan dengan adanya RPS dalam kegian perencanaan pembelajaran yang dilakukan oleh dosen. Sedangkan komponen perencanaan pembelajaran sudah terdapat di RPS antara lain, terdapat penentuan alokasi waktu, penentuan bahan atau materi ajar, penentuan media yang digunakan dan metode dalam pembelajaran.

Perencanaan pembelajaran creative learning dilakukan pada awal perkuliahan dengan menyusun beberapa tugas. Berdasarkan hasil wawancara dalam perencanaan creative learning dimulai dengan melihat materi materi apa saja yang akan dipelajari. Hal ini dilakukan dengan maksud untuk memetakan tugas dan materi dalam kelompok. Dosen juga menyiapkan beberapa perlengkapan antara lain kertas manila untuk menyusun mind mapping, meminta mahasiswa untuk membawa laptop setiap kelompok minimal 1 laptop dan membaca referensi yang digunakan.

\section{B. Permasalahan yang Muncul dalam Perencanaan Creative Learning}

Perencanaan merupakan pedoman dalam melaksanakan pelaksanaan pembelajaran. Mengingat pentingnya peran perencanaan creative learning, maka akan sangat fatal apabila dosen tidak menyusun perencanaan pembelajaran. Perencanaan pembelajaran yang dilaksanakan di Program Studi Pendidikan Guru Sekolah Dasar menunjukkan bahwa tidak semua pertemuan dapat dilaksakan creative learning. Hal ini disesuaikan dengan materi yang akan dipelajari setiap materi. 
Permasalahan yang pertama perubahan kurikulum yang diterapkan di perguruan tinggi. Dalam pemyusunan perencanaan creative learning disusun mengikuti kaidahkaidah dalam kurikulum. Minimnya pemahaman mahasiswa, karena mahasiswa tersebut masih pada semester 1. Sehingga diperlukan pemahaman yang kuat sehingga dapat dilaksanakan pelaksanaan creative learning sesuai dengan rencana. Selain itu terdapat beberapa permasalah yang muncul dari dalam dan dari luar. Faktor dari dalam antara lain guru sebagai perencana untuk mengimplementasikan pembelajaran. Pengalamanpengalaman yang dimiliki dosen mempengaruh cara mengeskplorasi materi yang direncanakan. Dari segi mahasiswa kurangnya literasi yang dilakukan oleh mahasiswa, budaya mengopi paste yang masih banyak dilakukan oleh mahasiswa, ketergantungan mahasiswa dengan internet sehingga referensi yang digunakan hanya menggunakan ebook.

\section{Solusi untuk Mengatasi Permasalahan dalam Perencanaan Creative Learning}

Factor penghambat tersebut tentunya juga diusahakan oleh pengampu untuk tidak dijadikan alasan bahwa pelaksanaan pembelajaran tidak dilakukan, sehingga pengampu berusaha semaksimal mungkin untuk mencarikan solusi dari beberapa factor penghambat tersebut. Solusi yang diberikan untuk mengatasi factor penghambat tersebut adalah :

a. Mahasiswa diharuskan mencari refesensi untuk pembuatan makalah paling sedikit 8 buku (boleh hard copy dan juga soft copy (ebook yang ber-ISBN atau jurnal yang ber-ISSN)

b. Pembuatan makalah diharuskan untuk mengambil rujukan dari beberapa buku dan kemudian diolah dengan menggunakan kata-kata sendiri

c. Ada syarat yang diberikan untuk mahasiswa yaitu buku yang berupa hard-copy yang digunakan sebagai rujukan minimal 4. Buku tersebut merupakan buku yang dijadikan dasar atau fondasi dalam penyususnan makalah, sedangkan jurnal yang dijadikan referensi sebagai referensi tambahan.

d. Mahasiswa dilarang untuk menyalin semua teori yang ada di buku, melainkan harus mengerjakan dengan menggunakan bahasa sendiri atau mengolah apa yang ada di buku menjadi bahasa sendiri namun dengan tetap menuliskan rujukannya.

e. Memberikan lesson plan kepada mahasiswa yang berisikan tentang tanggal serta kegiatan yang harus dilakukan oleh mahasiswa pada setiap tanggalnya, sehingga terdapat progress yang dinilai oleh pengampu untuk setiap waktu pembelajaran.

\section{PEMBAHASAN}

Berdasarkan hasil penelitian perencanaan creative learning sudah berjalan dengan baik. Pada umumnya pembelajaran kreatif merupakan proses pembelajaran yang mengharuskan pendidik dapat memotivasi dan memunculkan kreativitas peserta didik selama proses pembelajaran. Creative learning harus dapat merangsang peserta didik memunculkan kreatifitas, baik dalam konteks kreatif berpikir maupun dalam 
konteks kreatif melakukan sesuatu. Sehingga dalam perencaan creative learning yang dilakukan dalam penelitian ini melalui beberapa tahap.

Pembelajaran sebagai suatu proses kegiatan, terdiri atas beberapa fase atau tahapan. Kegaitan pembelajaran yang baik selalu berawal dari rencana yang matang. Perencanaan yang baik akan mempengaruhi hasil yang optimal dalam pembelajaran. Perencanaan merupakan proses penyusunan sesuatu yang akan dilaksanakan untuk mencapai tujuan yang telah ditentukan. Pelaksanakan perencanaan tersebut dapat disusun berdasarkan kebutuhan dalam jangka tertentu sesuai dengan keinginan pembuat perencana pembelajaran. Seorang pendidik sebagai subjek yang mempunyai peran pening dalam membuat perencanaan harus dapat menyusun berbagai program pengajaran sesuai dengan pendekatan yang akan digunakan.

Seorang pendidik harus memenuhi dua kategori yaitu memiliki capability dan loyality, yakni harus memiliki kemampuan dalam bidang ilmu yang diajarkan. Miliki kemampuan teoritik tentang mengajar yang baik, dari mulai perencanaan, implementasi sampai evalkuasi dan memiliki leyalitas keguruan, yakni loyal terhadap tugas-tugas keguruan yang tidak semata di dalam kelas, tapi sebelum dan sesudah kelas. Beberapa prinsip yang perlu diterapkan dalam membuat prinsip mengajar antara lain: memahami tujuan pendidikan, menguasai bahan ajar, memahami, teori-teori pendidikan selain teori pengajaran, prinsip-prinsip mengajar, metode mengajar, beberapa model pengajaran yang penting, prinsip evaluasi, dan langkah-langkah membuat lesson plan.

Berdasarkan hasil penelitian tersebut perencaan creative learning di mata kuliah profesi keguruan perencanaan tersebut adala muncul berdasarkan hasil dokumentasi yang ada di RPS. Langkah-langkah yang dikukan cenderung bersifat normatif, sedang teiru belajar bersifat deskriptif. Perencanaan pembelajaran kreatif memberikan ruang untuk mahasiswa mampu berpikir kreatif menuangkan ide untuk mengontruksi pemahamannya.

Tugas tugas yang dilakukan oleh mahasiswa pada mata kuliah profesi keguruan menunjukkan bahwa mahasiswa dapat menerjemahkan materi materi dalam kelompok melalui mind mapping. Lesson plan disusun beguna untuk memetakan cara belajar yang akan dilakukan selama satu semester. Hal ini berguna untuk memberikan persiapan kepada mahasiswa sebagai bekal informasi di dalam pembelajaran.

\section{KESIMPULAN}

Berdasarkan Perencanaan dalam creative learning memberikan inovasi dalam pelaksanaan pembelajaran. Melalui perencanaan pembelajaran yang baik maka pelaksnaaan pembelajaran juga dapat mencapai tujuan pembelajaran. Sehingga evaluasi dapat dilakukan sesuai perencaan yang sudah disiapkan. Peran perencanaan pembelajaran sangat penting, hal ini akan memberikan pengaruh terhadap kegiatan- 
kjegiatan selanjutnya. Perencanaan yang sudah dilakukan dalam creative learning adalah mulai mengoordinasikan dengan tim teaching, kemudian melanjutkan melihat capaian yang akan dicapai mahasiswa, membaca referensi yang berkaitan dengan profesi keguruan dan menuangkan dalam RPS. Rencana pembelajaran semester merupakan perencaan yang disiapkan dosen untuk melaksanakan kegiatan pembelajaran mulai pertemuan pertama hingga terakhir. Di dalam perencanaan pembelajaran kreatif, dosen telah melihat karakteristik dan perkembangan peserta didik. Di sampng ittu juga terlihat tugas tugas yang akan dilakukan mahasiswa. Tugas tugas tersebut adalah memulai dengan membagi kelompok secara heterogen, mengerjakan tugas berupa membuat mind mapping, makalah dan power point. Tugas tugas tersebut akan dilaksanakan secara berkala sesuai dengan lesson plan yang sudah ditetapkan.

\section{DAFTAR RUJUKAN}

Daryanto. (2009). Panduan Proses Pembelajaran Kreatif dan Inovatif. Jakarta: AV Publisher

Dodge, D.T., Colker, L.J., dan Heroman, Cate. (2002). The Creative Curriculum For Preschool. Washington DC: Teaching Strategies, Inc

Haryanti, T. (2015). Penerapan Strategi Pembelajaran Kreatif-Produktif Untuk Meningkatkan Kualitas Pembelajaran IPS Siswa Kelas V SDN Inpres 5 Birobuli, 4(7), 247-256.

Komalasari, Kokom. (2011). Pembelajaran Kontekstual Konsep dan Aplikasi. Bandung: PT Refika Aditama.

Munandar, Utami. (2009). Pengembangan Kreatifitas Anak Berbakat. Jakarta : Rineka Cipta

Putera, R. S. (2013). Desain Belajar Mengajar Kreatif Berbasis Sains. Jogjakarta: DIVA Press

Supriadi, Dedi. (1994), Kreativitas, Kebudayaan \& Perkembangan Iptek. Bandung: Alfabeta.

Uzer, Usman. (2006). Menjadi Guru Profesional. Bandung: Remaja Rosdakarya. 